\title{
Identification of an oestrus-associated glycoprotein in oviducal fluid of the sheep
}

\author{
R. Sutton, C. D. Nancarrow, A. L. C. Wallace and N. W. Rigby \\ CSIRO Division of Animal Production, PO Box 239, Blacktown, New South Wales 2148, Australia
}

\begin{abstract}
Summary. Samples of oviducal fluid were collected daily from sheep with indwelling catheters. Fluid samples taken from both oviducts of 2 sheep for 2 cycles during the middle of the breeding season (April/May) (8 sets of data) were compared with 9 sets of data generated from 2 cycles in 3 sheep later in the breeding season (June/July). Around the period of oestrus, the output of oviducal fluid increased to a peak volume of $1.56 \pm$ $0.35 \mathrm{ml}$ per day (mean \pm s.d.) compared with a mid-cycle volume of $0.49 \pm 0.29 \mathrm{ml}$. Later in the breeding season, the flow rates were lower, but showed the same trend $(0.91$ $\pm 0.24 \mathrm{ml}$ at the peak and $0.25 \pm 0.18 \mathrm{ml} 7$ days later). The total amount of protein secreted by the oviduct each day increased 2-4-fold around the time of oestrus, with higher levels in mid-season ewes. When oviducal fluids were fractionated by SDS electrophoresis, a novel glycoprotein, subunit size of $M_{r} 80-90000$ was identified in samples for 3-6 days of each cycle, coinciding with the period of high fluid flow rate. This protein first appeared in the oviducal fluid on the day of oestrus or the following day and it represented 1 of the 2 major glycoproteins in oviducal fluid as assessed by periodic acid-Schiff (PAS) staining. A PAS-positive protein $\left(M_{r} 80-90000\right)$ was also detected in fluid taken after oestrus on native highly cross-linked gradient gels after electrophoresis at $\mathrm{pH} 3 \cdot 1$ but not at $\mathrm{pH} 8 \cdot 3$. Both gradient gel systems showed an increase in high molecular weight material $\left(M_{r}>10^{6}\right)$ in fluid taken soon after oestrus.
\end{abstract}

\section{Introduction}

Oviduct fluid is the medium in which the mammalian egg is normally fertilized and in which the first few cell divisions of the embryo take place. Using oocytes from women or laboratory animals, such as mice, rats and rabbits, many workers have been able to achieve fertilization and early cleavage in vitro, resulting in normal pregnancies after transfer back to the mother or surrogate. However, studies on in-vitro fertilization of oocytes from domestic farm animals have been much less successful (Wright \& Bondioli, 1981). Only low levels of fertilization have been reported and these have generally been when the spermatozoa have been matured in vivo in the oviduct of the same or similar species, or when oocytes were collected from the oviduct. It is therefore possible that specific proteins in the oviducal fluid are needed to facilitate fertilization in sheep and cattle.

It has been suggested that the fertilized egg and developing embryo release a signal called 'ovum factor' (Cavanagh, Morton, Rolfe \& Gidley-Baird, 1982) or 'zygotin' (Nancarrow, Wallace \& Grewal, 1981). This factor, believed to be a peptide, diffuses through the oviducal fluid to induce either the oviduct and/or the ovary to produce a component of early pregnancy factor: a putative immunosuppressive agent produced within a few hours of fertilization (for review, Whyte \& Heap, 1983). Therefore, an examination of the proteins in oviducal fluid from oestrous or pregnant animals could reveal components which are important for fertilization, early embryonic development or maternal recognition of pregnancy.

The techniques for collecting oviducal fluid are well established and studies on a number of 
mammals, including sheep, cattle, pigs, rabbits, rats, monkeys and women, have shown that the rate of flow of oviducal fluid increases for a few days around the time of ovulation in response to oestrogen (for reviews, Perkins, 1972; Stone \& Hamner, 1975; Edwards, 1980). This paper describes the occurrence of a glycoprotein in ovine oviduct fluid from non-pregnant ewes when the flow rate is high after oestrus. Because a seasonal difference in the oviduct fluid flow rates has been observed (Murray, Goode \& Linnerud, 1969), samples were collected at a time corresponding to mid- and late breeding season.

\section{Materials and Methods}

\section{Collection of oviducal fluid}

Of the 7 Merino ewes used, 3 were catheterized on 14 April (mid-breeding season) and 4 on 15 June (late breeding season). Ewes were anaesthetized with $1 \mathrm{~g}$ thiopentone sodium and maintained with $\sim 2.5 \%$ fluothane in oxygen. Both oviducts were cannulated with Silastic tubing (i.d. $1.0 \mathrm{~mm}$, o.d. $2 \cdot 2 \mathrm{~mm}$ ) (Dow Corning, MI, U.S.A.). A small ridge of Silastic was moulded around the tubing 2 $\mathrm{mm}$ from the end which was secured into the top of the ampulla with Metric 2 silk. The uterotubal junction was ligated with the silk to ensure that no contamination with uterine secretions occurred. The catheter lines were externalized through the abdominal wall and connected to sterile collection vessels similar to those described by Roberts, Parker \& Symonds (1975). All sheep except No. 1 had a 375-mg progesterone implant (Sil Estrus; Ceva Chemicals, Australia), inserted 6-9 days before surgery and removed after the flow from the catheter had become established. Oviducal fluid was usually collected each morning. On the occasions when 48-h samples were collected, it was assumed that half of the volume resulted from each day. The fluid was collected in a 1-ml syringe and the volume was estimated by weighing. After centrifugation to remove cells and debris, the supernatant was collected and kept frozen in glass vials at $-20^{\circ} \mathrm{C}$. Once each week the pellets from the centrifuged fluid were examined by light microscopy for the presence of bacteria, fungi or blood cells. The presence of bacteria correlated well with apparent degradation of proteins observed on SDS gels.

The cannulation was considered to be successful in 9 catheters, in 5 of the 7 sheep used; 4 catheters became blocked within a few days and a 5th showed a very high erratic flow rate with high protein concentrations, suggesting the direct leakage of plasma or lymphatic fluid in the line. The 9 successful catheters functioned without problems for 2-5 cycles, although in some instances bacterial contamination occurred in later cycles. The results in this paper relate only to the first 2 cycles of any animal and only uncontaminated samples were included. Thus, samples from 2 cycles from both catheters of Ewes 1 and 2 (mid-April to mid-May) were compared with 2 cycles from Ewes 3 (both sides), 4 (left side) and 5 (right side) and the first cycle of Ewe 4 (right side) (mid-June to mid-July).

\section{Protein determinations}

The protein concentration of oviducal fluid samples was determined for 20-50 $\mu$ l fluid (diluted 1 in 80 or 1 in 150) by an absorbance method (Whitaker \& Granum, 1980). The concentration of protein is given by the formula $\mathrm{A}_{235}-\mathrm{A}_{280} / 2 \cdot 51$. This method gave results similar to those obtained by the method of Lowry, Rosebrough, Farr \& Randall (1951).

\section{Luteinizing hormone assay}

Plasma LH concentrations were measured using a radioimmunoassay described by Radford, Nancarrow \& Findlay (1978). The assay had a sensitivity of $0.25 \mathrm{ng}$, a CV of $9 \%$ and used NIH-LH$\mathrm{S} 15$ as standard. 


\section{Electrophoresis}

SDS electrophoresis was carried out using the discontinuous buffer system of Laemmli (1970) on polyacrylamide slab gels $17 \times 14 \mathrm{~cm}$ with a thickness of $0.7 \mathrm{~mm}$. The separating gel was $12 \%$ acrylamide with $0.01 \%$ bisacrylamide with a stacking gel of $3 \%$ acrylamide, $0.08 \%$ bisacrylamide. The molecular weight standards used were obtained from Pharmacia Uppsala, Sweden. Gels were stained using Coomassie blue R250 (Biorad, CA, U.S.A.) (0.1\% in ethanol:water:acetic acid, $50: 45: 5$ by vol.) and destained in ethanol: water: acetic acid (40:57:3 by vol.). Silver staining was performed using the method of Merril, Goldman, Sedman \& Ebert (1981) and reagents obtained from Biorad (CA, U.S.A.).

Gradient gel electrophoresis was performed on commercial gels (Gradipore Pty Ltd, Pyrmont, Australia) $8 \times 8 \mathrm{~cm} \times 3 \mathrm{~mm}$ with gradients of 3 to $40 \%$ acrylamide with 4 to $8 \%$ crosslinker which generates pores of decreasing size in the matrix (Campbell, Wrigley \& Margolis, 1983). Cathodic electrophoresis was run using sodium lactate buffer $\mathrm{pH} 3 \cdot 1$ (du Cros \& Wrigley, 1979) and anodic electrophoresis was performed with the discontinuous Tris- $\mathrm{HCl} / \mathrm{glycine}$ buffer system of Davis (1964). Gels were run at 100-120 V for 2000 volt hours. Samples were prepared in an appropriate buffer (pH 6.8) with glycerol and bromophenol blue or methyl green. Gels were stained in $0.025 \%$ Coomassie blue G 250 in $12 \%$ TCA (du Cros \& Wrigley, 1979). Periodic acid-Schiff staining for carbohydrate was carried out using modifications of the method of Fairbanks, Steck \& Wallach (1971), shortening the times used for $0.7 \mathrm{~mm}$ gels.

\section{Results}

The changes during the oestrous cycle in daily volume, total amount of protein per day and protein concentration of oviducal fluid are shown in Text-fig. 1. These results were derived from fluid collections over 8 cycles (both sides of 2 ewes) in mid-April to mid-May compared with 9 cycles ( 3 ewes) in mid-June to mid-July. To analyse changes during the oestrous cycle, days of the cycle were assigned by defining the day of the highest flow rate as Day 1 (except in 2 cases when this differed between the 2 catheters of the same animal, when the earlier peak day was taken as Day 1). Using this method, 15 cycles were 17 or 18 days long, one was 16 days and one 19 days. The flow rate of oviducal fluid was higher for about 4 days of each cycle both in the middle and later in the breeding season in Australia. There was also a seasonal effect, with higher flow rates in the animals catheterized during the April/May period. The cyclic increase in oviducal fluid flow rate also represented a large increase in amount of protein leaving the oviduct each day, being 2-4-fold higher than in the remainder of the cycle. The protein concentration of oviducal fluid varied considerably both within and between animals, although there was a decrease around oestrus in the ewes sampled in mid-season.

The composition of the proteins in oviducal fluid was examined using discontinuous SDS electrophoresis. The gels for portions of 2 cycles are shown in Pl. 1, Figs $1 \& 2$. The protein pattern for sheep oviducal fluid was similar to that obtained with sheep serum (not shown). The major protein in oviducal fluid was apparently sheep serum albumin since it ran in the same position as bovine serum albumin (the standard of $M_{5} 67000$ used in the final lane). A consistent finding for the results in this paper and for several cycles in other ewes was that in each cycle a new protein appeared in the oviducal fluid on those days when the fluid flow rate was elevated. This protein band ran behind (above) albumin and had an apparent molecular size of 80-90000 (see Day 0, 1 and 2 samples for Ewe 1, mid-season (Pl. 1, Fig. 1) and samples for Days 1, 2 and 3 of Ewe 4, late season (PI. 1, Fig. 2)).

The SDS gels of all the fluid samples from these ewes were silver stained to provide a more sensitive means of detection of this protein which usually stains a more orange colour compared to the brown of most proteins. The amount of this protein varied between different cycles, with the largest amount being present on the day of the peak volume or the day after in each cycle. However, 


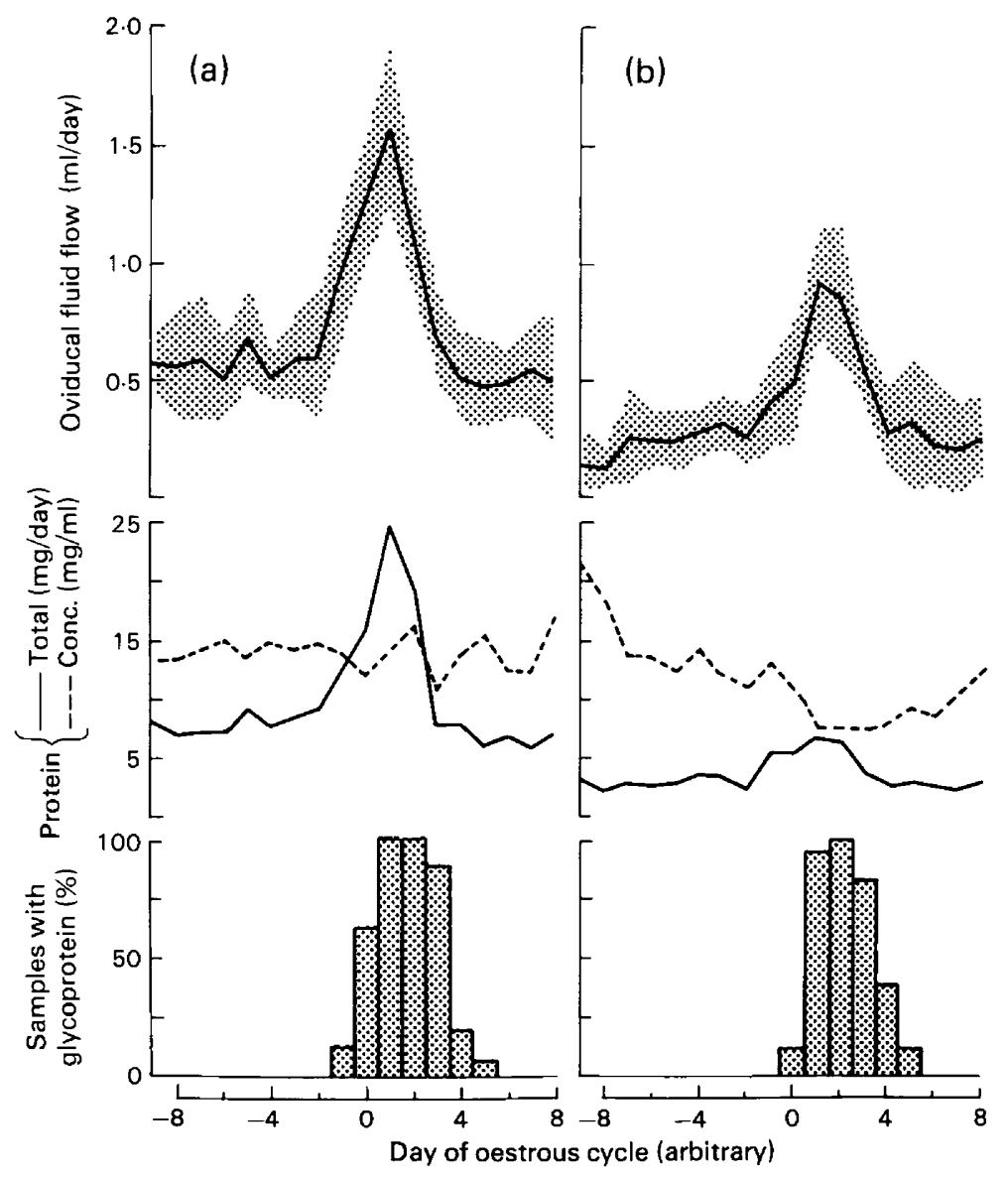

Text-fig. 1. Changes in oviducal fluid of sheep during the oestrous cycle. Data are given for daily fluid samples from (a) 8 oestrous cycles from 2 ewes (Nos 1 \& 2) collected in April/May (mid-breeding season) and (b) 9 cycles, 3 ewes (Nos 3, 4 \& 5) in June/July (late season). Values for fluid flow rate are mean \pm s.d.

no attempt was made to quantitate these changes. Samples were scored positive (1), negative (0) or barely detectable $(0 \cdot 5)$ and these data were then expressed as a percentage of the number of samples tested for each cycle day (Text-fig. 1). The protein was always present on the day of the highest flow rate of oviduct fluid (16 of the Day-1 samples were scored positive and the last as barely detectable) and on Day 2 (17/17 positive). This protein was usually present on Day 3, but was not detected between Day 6 and Day -2 of the next cycle of any of the sheep. It was present for $3.9 \pm 0.8$ days (mean \pm s.d.) in the mid-season ewes compared with $3.4 \pm 0.7$ days in late season animals.

The stage of the cycle at which this protein appeared was confirmed by measuring $\mathrm{LH}$ in daily plasma samples from Ewe 2 for 2 cycles and twice-daily samples from Ewes 4 and 5 for the first cycle. The time of bleeding, LH levels and presence or absence of the protein on each day are shown in Table 1. Minor disparities could arise in these results because each fluid sample represented production for about $24 \mathrm{~h}$ and blood for $\mathrm{LH}$ determinations was not taken more frequently. However, in 6 of the 7 series of fluid samples examined the protein was first detected on the same day as the LH peak. In the second cycle of Ewe 2, left side, the protein appeared in the oviducal fluid sample taken just before the plasma sample with high LH. In 3 of the oestrous cycles the highest LH level was recorded at the start of Day 1, while in the fourth (Ewe 5) it occurred on Day 0. 

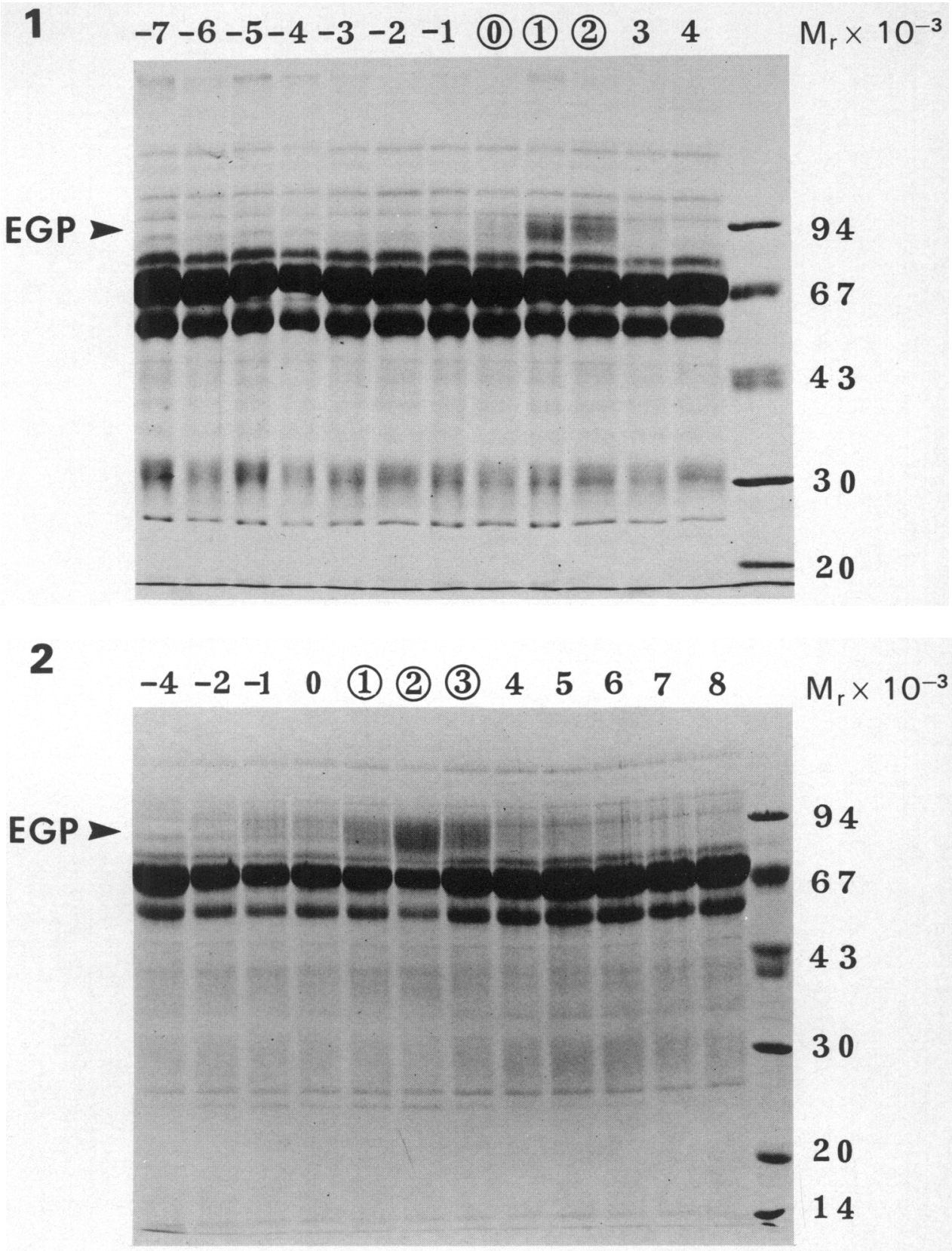

Fig. 1. SDS electrophoresis gel of oviducal fluid from different days of the oestrous cycle (indicated by the numbers) in the mid-breeding season of Ewe 1 (first cycle, right side). A volume containing $60 \mu \mathrm{g}$ protein was loaded in each lane except for the last lane which has low molecular weight standards. The number is circled over lanes in which the oestrus-associated glycoprotein (EGP) is visible.

Fig. 2. SDS electrophoresis gel of oviducal fluid samples taken late in the breeding season of Ewe 4 (first cycle, right side): $10 \mu$ l, i.e. $5 \mu$ l fluid $+5 \mu$ l extracting solution, were loaded per lane. The gel is labelled in the same way as Fig. 1. 


\section{PLATE 2}
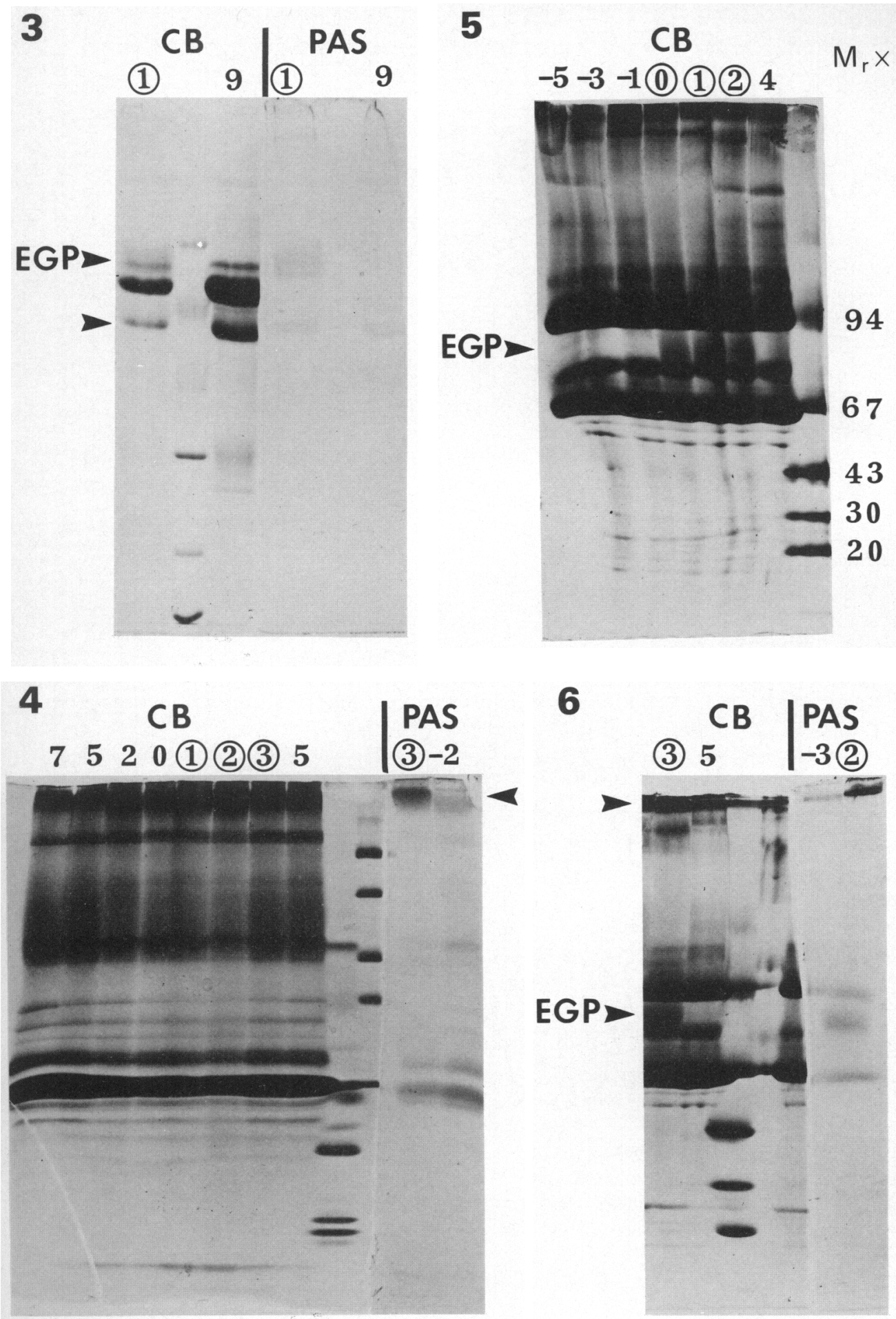
Table 1. Correlation of $\mathrm{LH}$ levels $(\mathrm{ng} / \mathrm{ml})$ in plasma with the presence of a glycoprotein in oviducal fluid of sheep

\begin{tabular}{|c|c|c|c|c|c|c|c|c|c|c|c|c|}
\hline \multirow[b]{3}{*}{$\begin{array}{l}\text { Assigned day } \\
\text { of cycle* }\end{array}$} & \multicolumn{6}{|c|}{ Mid-season ewes } & \multicolumn{6}{|c|}{ Late season ewes } \\
\hline & \multicolumn{3}{|c|}{ Ewe 2,1 st cycle } & \multicolumn{3}{|c|}{ Ewe 2, 2nd cycle } & \multicolumn{3}{|c|}{ Ewe 4, 1st cycle } & \multicolumn{3}{|c|}{ Ewe 5,1 st cycle } \\
\hline & $\begin{array}{l}\text { Time } \\
(\mathrm{h}) \dagger\end{array}$ & LH $\ddagger$ & EGP§ & $\begin{array}{l}\text { Time } \\
\text { (h) } \dagger\end{array}$ & LH $\ddagger$ & EGP§ & $\begin{array}{l}\text { Time } \\
(\mathrm{h})^{\dagger}\end{array}$ & LH $\ddagger$ & EGP§ & $\begin{array}{l}\text { Time } \\
\text { (h) } \dagger\end{array}$ & LH $\ddagger$ & EGP§ \\
\hline Day -2 & 0 & $\mathbf{P}$ & 0,0 & & & 0,0 & & & 0,0 & 7 & $\mathrm{P} \downarrow$ & 0 \\
\hline & & & 0,0 & & & 0,0 & 7 & $\mathrm{P} \downarrow$ & 0,0 & $4 \cdot 5$ & $1 \cdot 3$ & 0 \\
\hline Day 0 & 0 & 1.5 & 00 & 0 & $1 \cdot 1$ & 10 & $\begin{array}{l}0 \\
4 \cdot 5\end{array}$ & $\begin{array}{l}1 \cdot 1 \\
0.6\end{array}$ & 00 & $\begin{array}{l}0 \\
6\end{array}$ & $2 \cdot 1$ & 0.5 \\
\hline Day 1 & 0 & $>50 \cdot 0$ & 0,0 & 0 & $>50 \cdot 0$ & 1,0 & $\begin{array}{l}43 \\
0\end{array}$ & $\begin{array}{r}0.0 \\
30.0\end{array}$ & 0,0 & $\begin{array}{l}0 \\
0\end{array}$ & $\begin{array}{r}10 \cdot 0 \\
2 \cdot 0\end{array}$ & 0.5 \\
\hline Day 2 & 0 & $2 \cdot 7$ & $\begin{array}{l}1,1 \\
1,1\end{array}$ & 0 & $2 \cdot 4$ & 1,1 & $\begin{array}{l}6 \\
0 \\
7.5\end{array}$ & $\begin{array}{l}3.6 \\
0.0 \\
0.1\end{array}$ & $\begin{array}{l}1,1 \\
1,1\end{array}$ & 7.5 & 0.6 & 1 \\
\hline
\end{tabular}

* The day with the highest flow rate of oviducal fluid was arbitrarily defined as Day 1 of the cycle (see text). day.

$\uparrow$ The time of sampling of plasma is expressed as the number of hours since the beginning of fluid collection on that

$\ddagger \mathrm{P} \downarrow$ indicates the time of removal of progesterone implants.

$\S$ The presence (1) or absence (0) of oestrus-associated glycoprotein (EGP) in daily oviducal fluid samples was scored after silver staining of SDS gels. For Ewes 2 and 4 scores for the left and right oviduct fluids are shown. In Ewe 5 only fluid from the right side was available.

The data are therefore consistent with Day 0 being the day of oestrus with the appearance of the protein within $24 \mathrm{~h}$.

The diffuse nature of this band of protein suggested that it might be a glycoprotein with a degree of heterogeneity in the sugar moiety. This was confirmed by staining duplicate sections of a gel on which the oviducal fluid has been electrophoresed with periodic acid-Schiff reagent and Coomassie blue. Both stains showed a diffuse band $\left(M_{r} 80-90000\right)$ in the sample taken after oestrus but not in mid-cycle fluid (Pl. 2, Fig. 3). For convenience this protein has been referred to as the

\section{PLATE 2}

Fig. 3. SDS electrophoresis gel stained with Coomassie blue (CB) compared with Periodic acid-Schiff reagent (PAS) of oviducal fluid $(6 \mu 1)$ with and without oestrus-associated glycoprotein from Ewe 3 (right side). The middle lane in each case has low molecular weight standards. The glycoprotein is indicated by the arrow and circling of the day of cycle number. The second arrow points to a protein band present throughout the cycle which is PAS-positive.

Fig. 4. Highly cross-linked gradient gel with $3 \%$ (top) to $40 \%$ acrylamide, run with $\mathrm{pH} 8 \cdot 3$ buffer, of oviducal fluid from Ewe 4 (right side, first cycle as in Fig. 2). Protein $(90 \mu \mathrm{g})$ was loaded onto each lane and the gel was cut into 2 sections which were stained with Coomassie blue (CB) and PAS. The last 2 lanes stained with CB indicate low molecular weight and high molecular weight standards $\left(669,440,232,140\right.$ and $67 \times 10^{3}$ from top to bottom). Samples in which the oestrus-associated glycoprotein was detected by SDS electrophoresis are shown by circling the day of cycle number.

Fig. 5. Highly cross-linked gradient gel run with $\mathrm{pH} 3 \cdot 1$ buffer of oviducal fluid from Ewe 5 (right side) (100 $\mu$ g protein per lane). Samples in which the oestrus-associated glycoprotein was detected by SDS-electrophoresis are shown by circling the day of cycle number. The final lane shows low molecular weight standards $\left(\times 10^{-3}\right)$.

Fig. 6. Highly cross-linked gradient gel run with $\mathrm{pH} 3 \cdot 1$ buffer of oviducal fluid from Ewe 4 (right side first cycle) $(90 \mu \mathrm{g}$ protein per lane). The samples are, from left to right, fluid with oestrus-associated glycoprotein, fluid without the glycoprotein, low molecular weight standards, high molecular weight standards (poorly resolved), fluid without the glycoprotein (cut diagonally) and fluid with the oestrus-associated glycoprotein. 
oestrus-associated glycoprotein. A second glycoprotein that was present throughout the cycle was also identified with periodic acid-Schiff staining. This band corresponded to the major protein below albumin on the gels and may have been serum transferrin.

To determine the native molecular weight of the oestrus-associated glycoprotein appropriate oviducal fluid samples were fractionated by electrophoresis on highly cross-linked gradient gels. Electrophoresis was performed at low pH (cathodic migration) and high $\mathrm{pH}$ (anodic) to overcome

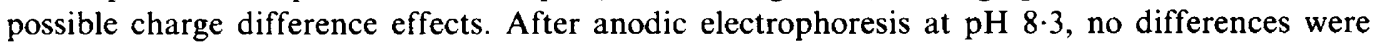
detected between samples taken on different days of the cycle from Ewe 4 in the region of the gel in which the monomer of the oestrus-associated glycoprotein would be expected to run $\left(M_{r} 80-90000\right)$ (Pl. 2, Fig. 4). However, there was apparently more protein at the top of the gel in the samples around the time of oestrus and moreover material in this region was more highly PAS-positive in the Day-3 compared with Day -2 sample. Since this protein is pore-limited by $4 \%$ acrylamide it would have a molecular weight of several million.

After cathodic electrophoresis ( $\mathrm{pH} \mathrm{3.1)} \mathrm{(Pl.} \mathrm{2,} \mathrm{Fig.} \mathrm{5)} \mathrm{a} \mathrm{diffuse} \mathrm{protein} \mathrm{band} \mathrm{was} \mathrm{detected} \mathrm{in}$ samples for Days 0 to 2 of Ewe 5 (right oviduct). The position of this band is consistent with a molecular weight of 80-90000. This band on the gel stained with PAS in the Day-1 sample (Ewe 4, right oviduct) (Pl. 2, Fig. 6) confirming that this is the oestrus-associated glycoprotein.

\section{Discussion}

The amounts of oviducal fluid produced at different stages of the oestrous cycle reported in this paper are similar to those described by others for the sheep (Restall, 1966; Iritani, Gomes \& VanDemark, 1969; Bellvé \& McDonald, 1970; Warnes, Amato \& Seamark, 1978). The results also confirm the observation of Murray et al. (1969) that the periovulatory increase in fluid flow rate is greater, earlier in the breeding cycle. Previous authors have reported similar low protein concentrations compared to serum, with fluctuations in concentration in individual animals and variation between animals. Perhaps because of this variation and the limited number of samples, there were no statistically significant trends in protein concentration reported (Restall \& Wales, 1966; Perkins \& Goode, 1966; Murray et al., 1969). The present results show a decrease in protein concentrations around oestrus in the June/July group. Since oviducal fluid in women also has a lower protein concentration around the time of ovulation (Lippes, Krasner, Alfonso, Dacalos \& Lucero, 1981), this may be the underlying trend beneath the variation.

The results are consistent with a method for oviducal fluid production developed for the rat which suggested that a protein-rich fluid is diluted in a variable manner with a protein-poor fluid (Shalgi, Kaplan \& Kraicer, 1977). Perhaps these components represent a selective transudate of plasma proteins and a larger volume of dilute fluid exuded from the epithelial cells and containing oviduct-specific proteins. It is known that, under the influence of oestrogen, secretory activity is increased in the oviducal epithelium around the time of ovulation (Edwards, 1980, review). It is also known that oestrogen causes an increase in capillary blood flow to the oviduct in sheep. There is a 2-3-fold increase in blood flow around the time of oestrus with a peak at Day -1 and a secondary peak on Day 4 (Brown \& Mattner, 1977). The peak in blood flow before oestrus may stimulate the rate of oviduct fluid production in some manner.

The major finding of this paper is that there is a glycoprotein which is present in oviducal fluid for a few days around the time of ovulation and afterwards. This protein appears on Day 0 or Day 1 of the cycle, as confirmed by plasma LH concentrations. It remains in the oviducal fluid while the fluid flow rate is high, a period of about 4 days. This oestrus-associated glycoprotein is therefore present until the time that the embryo moves into the uterus, about $96 \mathrm{~h}$ after the onset of oestrus.

After denaturation and dissociation of proteins which occurs in SDS electrophoresis, the

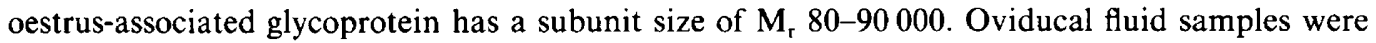
also run on highly cross-linked gradient gels to determine the native molecular weight of the 
protein. A PAS-positive band, $M_{r} \mathbf{8 0}-90000$, was detected in post-oestrus samples run on gradient gels run at low $\mathrm{pH}(3 \cdot 1)$ but not high $\mathrm{pH}(8 \cdot 3)$. Under both conditions, fluid samples containing the protein (as assessed by SDS electrophoresis) had more PAS-positive material in a high molecular weight zone of the glycoprotein $\left(>10^{6}\right)$ than did mid-cycle samples, suggesting that in its native state, at neutral $\mathrm{pH}$, at least some of the oestrus-associated glycoprotein may be present as a polymer or as an aggregate with other proteins or carbohydrates. Another interpretation of the gradient gel results would be that the $M_{r} 80-90000$ protein is unrelated to the high molecular weight material and that its absence on the $\mathrm{pH} 8 \cdot 3$ gel was caused by an isoelectric point of greater than $8 \cdot 3$ so that it migrated cathodically into the buffer and not into the gel.

Since the glycoprotein was not detected in serum (data not shown), and since the uterotubal junction was tied off as part of the catheterization procedure, it is likely that the oestrus-associated glycoprotein is synthesized by the oviduct. Willemse \& van Vorstenborsch (1975) reported that the production and release of granules from secretory cells of the epithelium of the sheep ampulla is much higher for the first few days of the oestrous cycle, which would correspond to the period that the oestrus-associated glycoprotein is being released into the fluid.

A search of the literature reveals many reports of specific proteins in oviducal fluid and several of these are produced or released under the influence of oestrogen (for reviews, see Mastroianni \& Go, 1979; Edwards, 1980). It is not always possible to compare the proteins described in the oviducal fluid of other species with the oestrus-associated glycoprotein in sheep because of the wide array of techniques that have been used to identify them. However, many of the other reported oviducal proteins have much lower molecular weights than the oestrus-associated glycoprotein and several are known to be PAS-negative, and are therefore not analogous. We cannot, however, exclude the possibility that proteins similar to the oestrus-associated glycoprotein are present in other species, since their high molecular weight would prevent them from being detected in most non-dissociating polyacrylamide gel electrophoresis systems (the oestrus-associated glycoprotein is pore-limited by $\sim 4 \%$ polyacrylamide, but $6 \%$ or $7.5 \%$ is commonly used). Indeed Roberts et al. (1976) in a thorough search utilizing 3 polyacrylamide gel systems failed to detect the oestrusassociated glycoprotein in sheep oviducal fluid although a large peak of high-molecular weight protein eluting in the void volume of a Sephadex G100 gel was found to be greater in oviducal fluid from oestrous than mid-cycle sheep. Using similar conditions, we have confirmed that this is where the oestrus-associated glycoprotein elutes (R. Sutton \& A. L. C. Wallace, unpublished). Therefore, the use of gel filtration, or electrophoresis on large pore matrices such as agarose, starch or cellulose acetate, may reveal similar proteins in a variety of species.

However, there is one protein which has already been described and which may be equivalent to the oestrus-associated glycoprotein. Shapiro, Brown \& Yard (1974) reported the presence of a large glycoprotein (subunit size $\mathbf{M}_{\mathrm{r}} 73000$ ) in oviducal fluid from oestrous rabbits. Using antisera they were able to demonstrate that this protein is present on the surface of 3-day but not 4-day-old embryos which have lost the mucin coat that is deposited on early rabbit embryos in the oviduct. Shapiro et al. (1974) concluded that this protein forms a high molecular weight aggregate with other components to make up the mucin coat of early rabbit embryos. Although such a coat is not clearly visible in embryos of other species such as sheep, it is possible that oviducal proteins in these species do bind to the ovum and facilitate fertilization or early development.

We thank R. Newman and H. Engel for expert technical assistance and J. Avenell and M. Radford for performing the LH assays.

\section{References}

Bellvé, A.R. \& McDonald, M.T. (1970) Directional flow of Fallopian tube secretion in the ewe at onset of the breeding season. $J$. Reprod. Fert. 22, 147-149.

Brown, B.W. \& Mattner, P.E. (1977) Capillary blood flow in the genital tracts of conscious ewes: cyclic changes and the effect of ovarian hormones. $J$. Endocr. 74, 185-191.

Campbell, W.P., Wrigley, C.W. \& Margolis, J. (1983) 
Electrophoresis of small proteins in highly crosslinked polyacrylamide gradient gels. Analyt. Biochem. 129, 31-36.

Cavanagh, A.C., Morton, H., Rolfe, B.E. \& Gidley-Baird, A.A. (1982) Ovum factor: a first signal of pregnancy. Am. J. Reprod. Immunol. 2, 97-101.

Davis, B.J. (1964) Disc electrophoresis. II. Method and application to human serum proteins. Ann. N.Y. Acad. Sci. 121, 404-427.

du Cros, D.L. \& Wrigley, C.W. (1979) Improved electrophoretic methods for identifying cereal varieties. $J$. Sci. Food Agricult. 30, 785-794.

Edwards, R.G. (1980) The female reproductive tract. In Conception in the Human Female, Ch. 6, pp. 416-524. Academic Press, London.

Fairbanks, G., Steck, T.L. \& Wallach, D.F.H. (1971) Electrophoretic analysis of the major polypeptides of the human erythrocyte membrane. Biochemistry, N.Y. 10, 2606-2617.

Iritani, A., Gomes, W.R. \& VanDemark, N.L. (1969) Secretion rates and chemical composition of oviduct and uterine fluids in ewes. Biol. Reprod. 1, 72-76.

Laemmli, U.K. (1970) Cleavage of structural proteins during the assembly of the head of bacteriophage T4. Nature, Lond. 227, 680-685.

Lippes, J., Krasner, J., Alfonso, L.A., Dacalos, E.D. \& Lucero, R. (1981) Human oviductal fluid proteins. Fert. Steril. 36, 623-629.

Lowry, O.H., Rosebrough, N.J., Farr, A.L. \& Randall, R.J. (1951) Protein measurement with the Folin phenol reagent. J. biol. Chem. 193, 265-275.

Mastroianni, L., Jr \& Go, K.J. (1979) Tubal secretions. In The Biology of the Fluids of the Female Reproductive Tract, pp. 335-344. Eds F. K. Beller \& G. F. B. Schumacher. Elsevier/North Holland, Amsterdam.

Merril, C.R., Goldman, D., Sedman, S.A. \& Ebert, M.H. (1981) Ultrasensitive stain for proteins in polyacrylamide gels show regional variation in cerebrospinal fluid proteins. Science, N.Y. 211, 1437-1438.

Murray, F.A., Goode, L. \& Linnerud, A.C. (1969) Effects of season, mating and pregnancy on the volume and protein content of ewe oviduct fluid. J. Anim. Sci. 29, 727-733.

Nancarrow, C.D., Wallace, A.L.C. \& Grewal, A.S. (1981) The early pregnancy factor of sheep and cattle. $J$. Reprod. Fert., Suppl. 30, 191-199.

Perkins, J.L. (1972) Fluid flow of the oviduct. In The Oviduct and its Functions, pp. 119-132. Eds A. D. Johnson \& C. W. Foley. Academic Press, New York.

Perkins, J.L. \& Goode, L. (1966) Effects of stage of the estrous cycle and exogenous hormones upon the volume and composition of oviduct fluid in ewes. $J$. Anim. Sci. 25, 465-471.

Radford, H.M., Nancarrow, C.D. \& Findlay, J.K. (1978) Effect of anaesthesia on ovarian follicular development and ovulation in the sheep subsequent to prostaglandin-induced luteolysis. J. Endocr. 78, 321327.

Restall, B.J. (1966) The fallopian tube of the sheep II. The influence of progesterone and oestrogen on the secretory activities of the fallopian tube. Aust. J. biol. Sci. 19, 687-697.

Restall, B.J. \& Wales, R.G. (1966) The fallopian tube of the sheep III. The chemical composition of the fluid from the fallopian tube. Aust. J. biol. Sci. 19, 687-698.

Roberts, G.P., Parker, J.M. \& Symonds, H.W. (1975) Proteins in the luminal fluid from the bovine oviduct. J. Reprod. Fert. 45, 301-313.

Roberts, G.P., Parker, J.M. \& Symonds, H.W. (1976) Macromolecular components of genital tract fluids from the sheep. J. Reprod. Fert. 48, 99-107.

Shalgi, R., Kaplan, R. \& Kraicer, P.F. (1977) Proteins of follicular, bursal and ampullar fluids of rats. Biol. Reprod. 17, 333-338.

Shapiro, S.S., Brown, N.E. \& Yard, A.S. (1974) Isolation of an acidic glycoprotein from rabbit oviducal fluid and its association with the egg coating. J. Reprod. Fert. 40, 281-290.

Stone, S.L. \& Hamner, C.E. (1975) Biochemistry and physiology of oviductal secretions. Gynecol. Invest. 6, 234-252.

Warnes, G.M., Amato, F. \& Seamark, R.F. (1978) Prostaglandin $\mathrm{F}$ in the fallopian tube secretion of the ewe. Aust. J. biol. Sci. 31, 275-282.

Whitaker, J.R. \& Granum, P.E. (1980) An absolute method for protein determination based on difference in absorbance at 235 and $280 \mathrm{~nm}$. Analyt. Biochem. 109, 156-159.

Whyte, A. \& Heap, R.B. (1983) Early pregnancy factor. Nature, Lond. 304, 121-122.

Willemse, A. \& van Vorstenborsch, D.J.A.H.U. (1975) The secretory activity of the epithelium of the ampulla tubae in cyclic ewes: an electron microscopical study. Tijdschr. Diergeneek 100, 95-105.

Wright, R.W., Jr \& Bondioli, K.R. (1981) Aspects of in vitro fertilization and embryo culture in domestic animals. J. Anim. Sci. 53, 702-729.

Received 13 February 1984 